\title{
Relationship between halophyte distribution and soil environmental factors in the west coast of South Korea
}

\author{
Seung Ho Lee ${ }^{1}$, Jeom-Sook Lee² and Jong-Wook Kim³
}

\begin{abstract}
Background: The objective of this study was to determine the relationship between soil environmental factors and halophyte distribution in the west coast of South Korea. Soils of our study sites were categorized into two groups: salt marsh and estuary marsh.

Results: Salinity was higher in the salt marsh group than that in the estuary marsh group. However, total nitrogen, silt, and clay contents were higher in the estuary marsh group than those in the salt marsh group. Although altitude had a wider range in the salt marsh group, the mean altitude was higher in the estuary marsh group than that in the salt marsh group. Annual halophytes of seed propagation species were distributed parallel to the coast line on salt marsh. Higher coverage of vegetation was found in the area closer to the coast line. Plant density was higher near dead parental plants in estuary marsh, showing less difference in area that was more distant from the coast line.
\end{abstract}

Conclusions: Results of canonical correspondence analysis (CCA) for vegetation distribution and sediment environmental factors and germination analysis in the coast line showed significant relationship with halophyte distribution. Therefore, they can be used as an indicator of coastal plant movement due to sea level rise.

Keywords: Estuary marsh, Salt marsh, Halophyte distribution, Soil factor, CCA, Altitude

\section{Background}

In Korea, marshes of the east coast are not well developed, although those of the west coast are extensively developed (Ihm and Lee 1998). The west coast is the leading tideland characterized by large difference in ebb and flow of tides (about $8 \mathrm{~m}$ ). Coastal wetlands such as salt marsh, salt swamp, and sand dune on the Korean Peninsula can be continuously found along the west coast. Because halophyte is developed in the upper intertidal zone, coastal wetlands have various ecological functions. They are ecotonal habitats with distinct ecosystems that connect both land and marine ecosystems. They provide important wildlife habitats for endangered species (Lee 2011; Lee et al. 2014a, b; Cho et al. 2017). They also increase biodiversity, decrease outer physical influence such as wave and current, and prevent coastal erosion (Kim et al. 2008; Lee 2011; Lee et al. 2014a, b).

\footnotetext{
*Correspondence: keco@mokpo.ac.kr

${ }^{3}$ Department of Biological Science, Mokpo National University, Muan-gun 58554, South Korea

Full list of author information is available at the end of the article
}

Pollutants from various wastewater of land can be adsorbed by salt marsh soil (Viles and Spencer 1995; Alhdad et al. 2015). In addition, pollutants can be purified naturally by animals, plants, and microorganisms inhabiting in the salt marsh soil (Lee and Yoon 1999; Park 1999; Kim et al. 2008; Lee et al. 2009; Lee 2011; Xie et al. 2017).

Zonation occurs in coastal wetlands of the southwestern coast. A wetland is an ideal habitat to study the relationship between distribution of species and environmental gradients (Lee et al. 2016). It is important to understand halophyte development and perform health assessment (Lee 2011; Lee et al. 2014a, b; Ivajnsic et al. 2016). When halophyte vegetation develops, the velocity of current flow will decrease and sediment will accumulate. Halophyte leaves dead bodies and roots in sediment layers to form new communities. Coastal wetlands have received attention recently due to their function in carbon sequestration and climate change adaptation (Cahoon et al. 1996; Rogel et al. 2000; Costa et al. 2003; Davidson-Amott et al. 2002; Kirwan and Guntenspergen 2012; Liu et al. 2015). 
In South Korea, salt marshes have various vegetation distributions with high species diversity due to environmental gradients and zonations. Because salt marshes have been used for development purposes for several decades, distinct sediment geomorphology and marine species communities have been partially destroyed. Both quality and quantity of possible ecological services arising from the ecological function of salt marsh ecosystem have been deteriorated (Hong 2000; Maeng et al. 2007; Lee et al. 2014a, b).

Recently, researchers have attempted to restore salt marsh and estuary marsh (Chung and Park 1978; Ihm and Lee 1998; Glenn et al. 2006; Konisky et al. 2006: Nyman et al. 2006; Cho et al. 2017). To restore salt marsh and estuary marsh with balanced functions, the relationship between salt marsh halophyte communities and soil physico-chemical factors should be studied first. It is also important to identify appropriate methods to induce halophyte communities considering both environmental and biological factors.

Therefore, the objective of this study was to determine halophyte distribution in two types of soil (salt marsh and estuary marsh) in South Korea and analyze the relationship between halophyte distribution and soil environmental factors in the west coast of South Korea using canonical correspondence analysis (CCA) and germination rate analysis.

\section{Results}

\section{Halophyte distribution}

Of different study areas (Fig. 1), Yeongjong (S3) had the least diverse halophyte distribution with 4 families and 6 species, while Daebudo (S6) (9 families and 18 species) and Hyeonhwa (S13) (8 families and 19 species) had the most diverse halophyte distribution (Fig. 2). The latter two areas also had diverse soil environmental factors and complex topography (Fig. 3).

\section{Habitat and soil environment factors}

In this study, two vegetation groups (group 1 and group 2) were recognized (Fig. 4). Group 1 had distinct salt marsh vegetations, including Aster tripolium, Suaeda asparagoides, and Phacelurus latifolius. Salt and estuary marshes shared seven common vegetations: Phragmites communis, Carex scabrifolia, S. japonica, Triglochin maritimum, S. maritima, Salicornia herbaceae, and Limonium tetragonum. Group 2 had distinct estuary marsh vegetations, including Zoysia sinica, Calystegia soldanella, Artemisia fukudo, and Elymus mollis.

Soil factors were analyzed for both salt marsh and estuary marshes (Fig. 1). For salt marsh and estuary marsh soils, $\mathrm{pH}$ values were $6.64 \pm 0.42$ and $6.95 \pm 0.36$, respectively. Moisture contents were $21.47 \pm 8.02$ and $25.45 \pm 4.07 \%$, respectively. Total organic carbon contents were $2.97 \pm 1.74$ and $4.27 \pm 1.97 \%$, respectively. Salinity values were $1.52 \pm 0.92$ and $1.23 \pm 0.94$, respectively. Electrical conductivity values were $2823.84 \pm 1700.16$ and $2312.07 \pm 1604.10 \mu$ s, respectively. Total nitrogen contents were $0.31 \pm 0.20$ and $0.36 \pm$ $0.21 \mathrm{mg} / \mathrm{g}$, respectively. Average soil A-P contents were $158.05 \pm 130.17$ and $102.68 \pm 122.77 \mu \mathrm{g} / \mathrm{g}$, respectively. Gravel contents were $5.93 \pm 8.32$ and $0.09 \pm 0.22 \%$, respectively. Sand contents were $60.32 \pm 23.25$ and $39.71 \pm 25.49 \%$, respectively. Silt and clay contents in salt marsh were $21.69 \pm 18.23$ and $45.00 \pm 15.29 \%$, respectively. They were $12.16 \pm 11.24$ and $15.20 \pm 16.61 \%$, respectively, in estuary marsh. Altitude was $1.17 \pm 1.32 \mathrm{~m}$ in salt marsh and $3.14 \pm 1.33 \mathrm{~m}$ in estuary marsh. Therefore, soil $\mathrm{pH}$, soil moisture, total organic carbon, total nitrogen, silt and clay contents, and altitude were higher in estuary marsh while soil salinity, electrical conductivity, soil A-P, gravel, and sand contents were higher in salt marsh.

\section{Ordination}

CCA ordination results of coastal wetland data set are shown in Fig. 4. A total of 14 community scores were plotted along axes 1 (Eigenvalue 0.021) and 2 (Eigenvalue 0.003). They tended to be clustered into two groups: the salt marsh group and the estuary marsh group. Based on correlation coefficients of environmental factors with the first CCA axis, axis 1 was highly correlated with gravel, silt, $\mathrm{pH}$, and altitude while axis 2 was correlated with $\mathrm{MC}$, TOC, and T-N (Table 1). In salt marshes, annual halophyte germinated in tidal level of the upper part of the coast line (Figs. 4, 5, and 6) while halophyte seedlings occurred in the same or similar altitude with dead parental plants (Fig. 6).

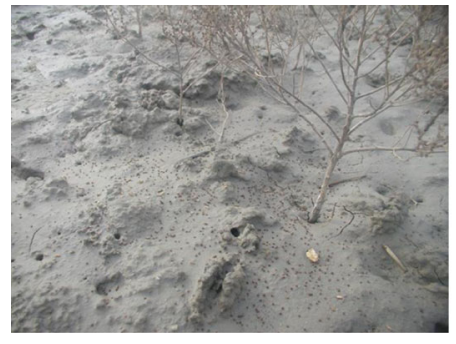

January 2004

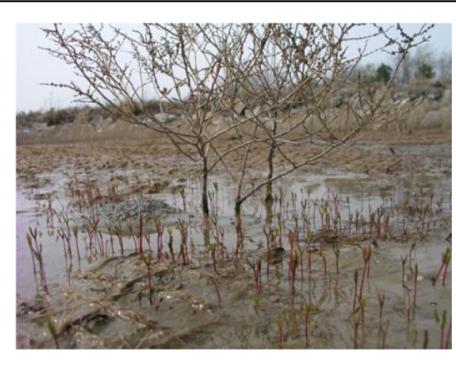

April 2004

Fig. 1 A map showing study sites including Suaeda japonica communities in the west coast of South Korea 

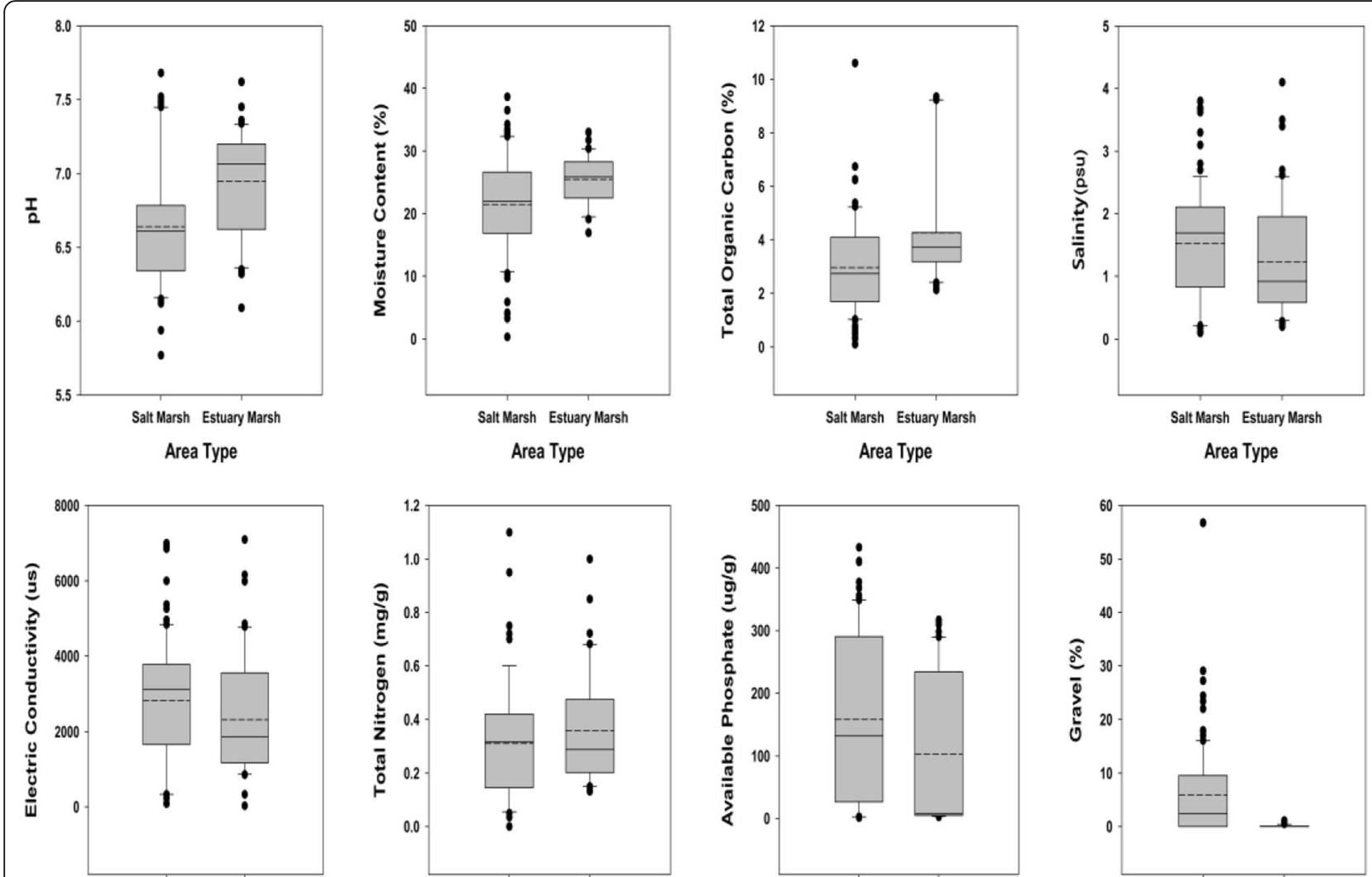

Salt Marsh Estuary Marsh

Area Type

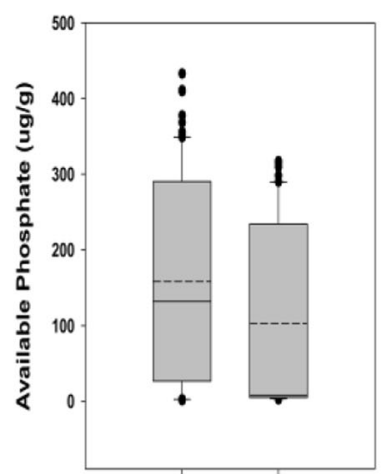

Salt Marsh Estuary Marsh

Area Type

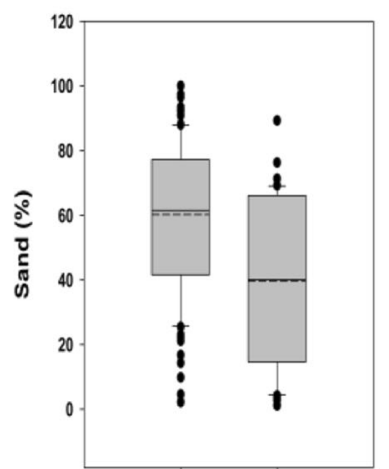

Salt Marsh Estuary Marsh

Area Type

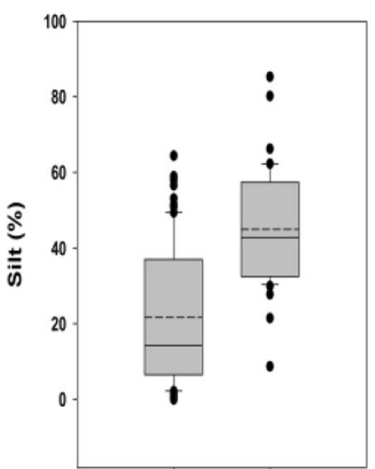

Salt Marsh Estuary Marsh

Area Type
Salt Marsh Estuary Marsh

Area Type

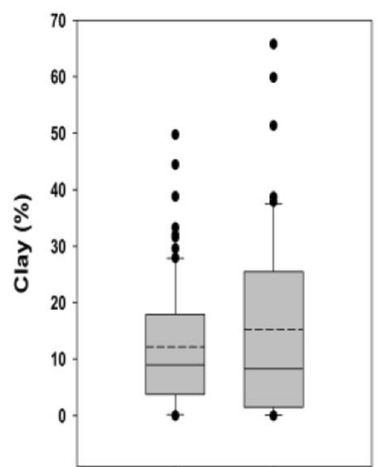

Salt Marsh Estuary Marsh

Area Type
Salt Marsh Estuary Marsh Area Type

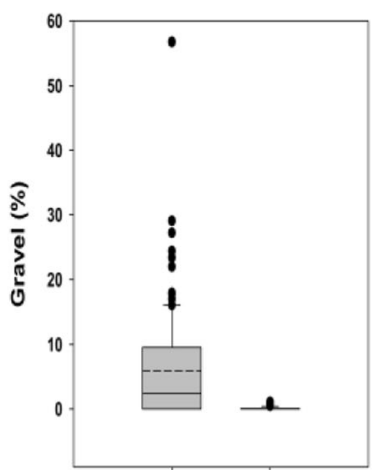

Salt Marsh Estuary Marsh Area Type

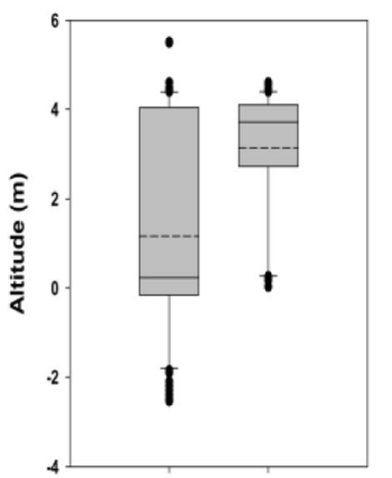

Salt Marsh Estuary Marsh

Area Type

Fig. 2 Number of species and family at the 13 study sites from July 2004 to August 2014

\section{Discussion}

\section{Halophyte distribution}

In the study area, Suaeda japonica, Carex scabrifolia, Triglochin maritimum, Phragmites communis, Limonium tetragonum, S. maritima, Salicornia herbaceae, Zoysia sinica, Artemisia fukudo, Elymus mollis, Calystegia soldanella, S. asparagoides, Phacelurus latifolius, and Aster tripolium were found (Figs. 1 and 7). Distinct zonation patterns occurred according to various soil characteristics and tidal levels (Figs. 4 and 5), consistent with previous reports (Lee 2011; Lee et al. 2016).

\section{Habitat characteristics and soil factors}

Difference between salt marsh and estuary marsh might be due to geographical position and vegetation growth. The development of estuary marsh is related to sedimentation in rivers and tides (Viles and Spencer 1995; Park 2000; Oh and Bang 2003). Halophyte distribution patterns can 


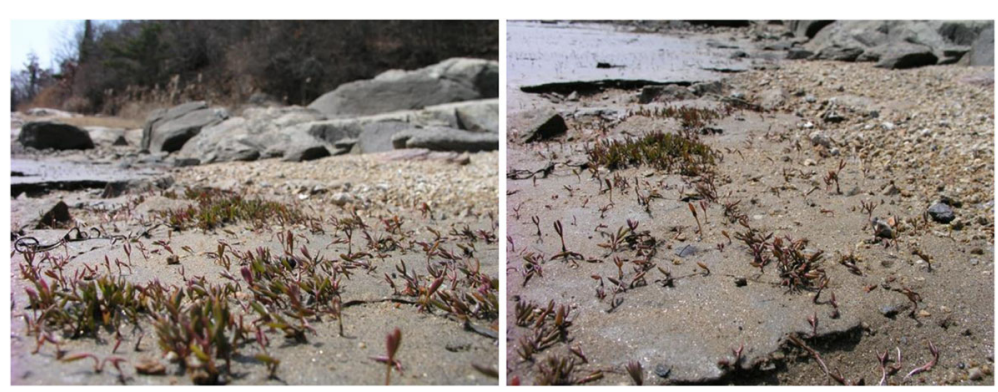

Fig. 3 Box and whisker plots for environmental factors of soil in plant communities of salt marsh and estuary marsh at the 13 study sites (--- mean, - median)

change according to the development of sedimentation geomorphology and soil texture (Lee 2011; Ihm et al. 2007) as well as time duration of tidal flooding (Park 2008). Outer physical influence can also affect salt marsh sediment (Hong 2000; Korea Environment Institute 2006). Seed burial in the sediment or flow of dispersed seeds might have a larger effect on salt marsh than that on estuary marsh.

Ihm et al. (2007) and Cho et al. (2017) have recognized halophyte types as salt marsh, salt swamp, and sand dune in CCA and TWINSPAN classification based on species coverage. The salt marsh species group (group 2) in this study showed association with Artemisia scoparia, Aster tripolium, Atriplex gmelini, Limonium tetragonum, S. herbaceae, S. asparagoides, S. japonica, S. maritima, and Z. sinica. Salt-swamp species groups (groups 1 and 4) contained $C$. scabrifolia, P. communis, Scirpus fluviatilis, T. maritimum, and $P$. latifolius. Sand dune species group (group 3) showed association with Carex kobomugi, Messerschmidia sibirica, Carex pumila, E. mollis, Ischaemum anthephoroides, Ixeris repens, Lysimachia mauritiana, Salsola komarovi, and Vitex rotundifolia. After examining environmental correlates of species distribution within these three habitat types using DCA and CCA ordination results of coastal plant data set, Ihm et al. (2007) have shown similar ordination results.

Salt marsh communities in this study showed distribution along gravel and sand gradients while estuary marsh communities showed distribution along and soil factors such as TOC, silt, and MC (Fig. 4, Table 1). They tended to be clustered into the salt marsh group and new estuary marsh group. These results are consistent with previous results of

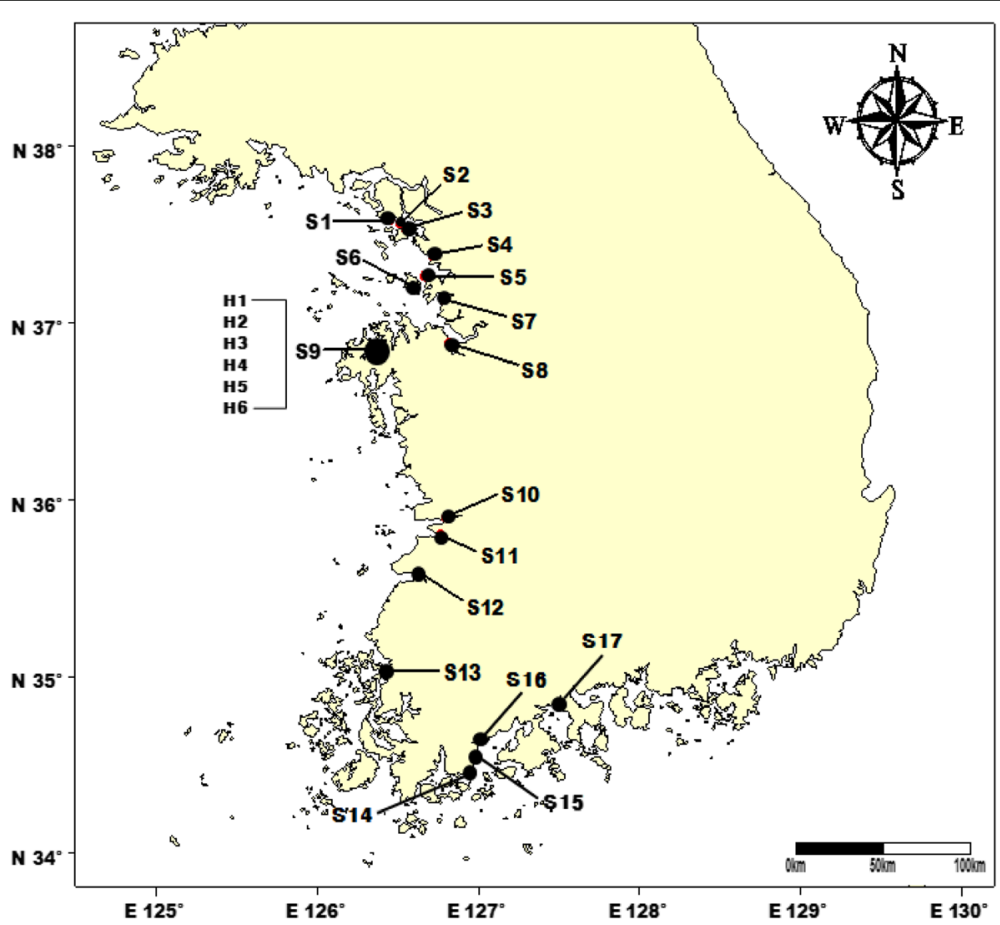

Fig. 4 CCA ordination diagram showing the relationship between plant species and soil properties of salt marsh and estuary marsh in the west coast of South Korea. Pc, Phragmites communis; Csc, Carex scabrifolia; Sj, Suaeda japonica; Tm, Triglochin maritimum; Zs, Zoysia sinica; Sm, Suaeda maritima; At, Aster tripolium; Sh, Salicornia herbaceae; Cso, Calystegia soldanella; Lt, Limonium tetragonum; Sa, Suaeda asparagoides; PI, Phacelurus latifolius; Af, Artemisia fukudo; Em, Elymus mollis (S, salt marsh; E, estuary marsh) 
Table 1 Canonical coefficient and intraset correlation of salt marsh and estuary marsh for the 12 environmental factors

\begin{tabular}{|c|c|c|c|c|}
\hline \multirow[t]{2}{*}{ Variable } & \multicolumn{2}{|c|}{ Canonical coefficient } & \multicolumn{2}{|c|}{ Intraset correlation } \\
\hline & Axis 1 & Axis 2 & Axis 1 & Axis 2 \\
\hline Gravel (\%) & 0.015 & 0.094 & 0.413 & 0.111 \\
\hline Sand (\%) & 0.001 & 0.293 & 0.187 & -0.218 \\
\hline Silt (\%) & -0.062 & 0.246 & -0.489 & 0.061 \\
\hline Clay (\%) & -0.015 & 0.163 & 0.079 & 0.251 \\
\hline $\mathrm{pH}$ & -0.022 & 0.003 & -0.402 & -0.244 \\
\hline M.C. (\%) & 0.093 & -0.045 & -0.073 & -0.684 \\
\hline TOC (\%) & -0.102 & -0.012 & -0.384 & -0.807 \\
\hline Salinity (PSU) & -0.345 & 0.059 & -0.055 & 0.278 \\
\hline E.C. (us) & 0.237 & -0.040 & -0.066 & 0.250 \\
\hline T-N (mg/g) & 0.021 & -0.007 & 0.005 & -0.534 \\
\hline A-P $(\mu \mathrm{g} / \mathrm{g})$ & 0.101 & -0.002 & 0.386 & 0.160 \\
\hline Altitude (m) & -0.051 & -0.017 & -0.522 & -0.272 \\
\hline
\end{tabular}

halophyte distribution by salinity and soil texture (Cho et al. 2017), soil particle size on coastal dunes (Lee et al. 2007), soil factor gradient (Lee et al. 2009), and soil texture (Ihm et al. 2007; Kim et al. 2006). In a previous study for this region, a regression model has shown that the abundance of 14 coastal plant communities in salt marshes is dependent on soil $\mathrm{pH}$, osmotic potential, and sand content (Ihm et al. 2006). In principal component analysis (PCA) of 12 soil properties (Ihm and Lee 1998), when 24 coastal plant communities were plotted in the space defined by the first two PCA axes, axes I and II accounted for 70 and 14\% of total variances, respectively. In PCA, axis I was designated as a gradient for soil texture and water potential related to salinity. On PCA axis 1 , coastal plant communities could be divided into the following three groups: (1) salt-marsh communities characterized by low water and osmotic potentials, high electrical conductivity, and elevated sodium and chloride contents; (2) salt swamp communities with moderate properties; and (3) sand dune communities with higher water and osmotic potentials but low sodium and chloride contents. These PCA results are consistent with conclusions drawn from our DCA and CCA.

As a result, halophyte distribution was affected by habitat characteristics such as soil physico-chemical factors and geomorphology. In this study, two habitat types had different environment characteristics factors. Soil factors were affected by outer physical influence such as tide level, tide current, and wave. Soil factor changes had a large effect on seed burial in sediment or flow of dispersed seeds.

Because seeds of $S$. japonica are small in size with low specific gravity, their seeds might have been flooded to the upper intertidal zone by flood tide. With a lower flow rate, more seeds might have established in flat geomorphology in Korea and Japan (Figs. 3, 4, 5, and 6; Wells et al. 1990; Alexander et al. 1991; Yokoishi and Tanimoto 1994; Min 2005; Sin and Kim 2010). Early germination rate was higher in the upper intertidal zone due to a higher seed sediment rate. After germination but before root development, seedlings could not establish. They can be withered due to root exposure to wave and current (Bird 1984; Choi 1993; Lee 2011; Gul et al. 2013). Therefore, early seedling establishment rate due to outer physical influence may determine individual maintenance, distribution range, and coverage of halophytes.

In salt marsh, seed germination rate was higher near dead parental plants with lower flood duration and frequency (buried seeds of Suaeda japonica 8954 (S2) and 2643 (S1) and seed germination rate $31.3 \mathrm{~m}^{2}$ (S2) and $\left.8.4 \mathrm{~m}^{2}(\mathrm{~S} 1)\right)$. As a result, seed germination was restricted due to lower effect of tide level and tidal current (Fig. 6; Harper 1977; Hubbel 1980; Okubo and Levin 1989; Willson 1992; Dalling et al. 1998; Min 2000, 2005).

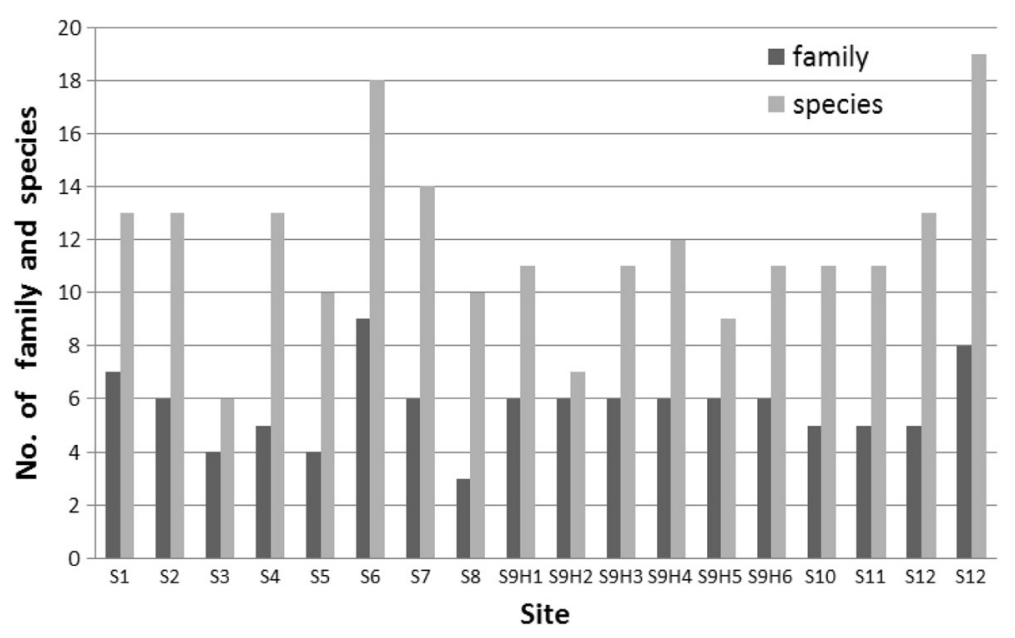

Fig. 5 Sprout density of Suaeda japonica at germination time in salt marsh at Donggeom (S2) in April of 2004 


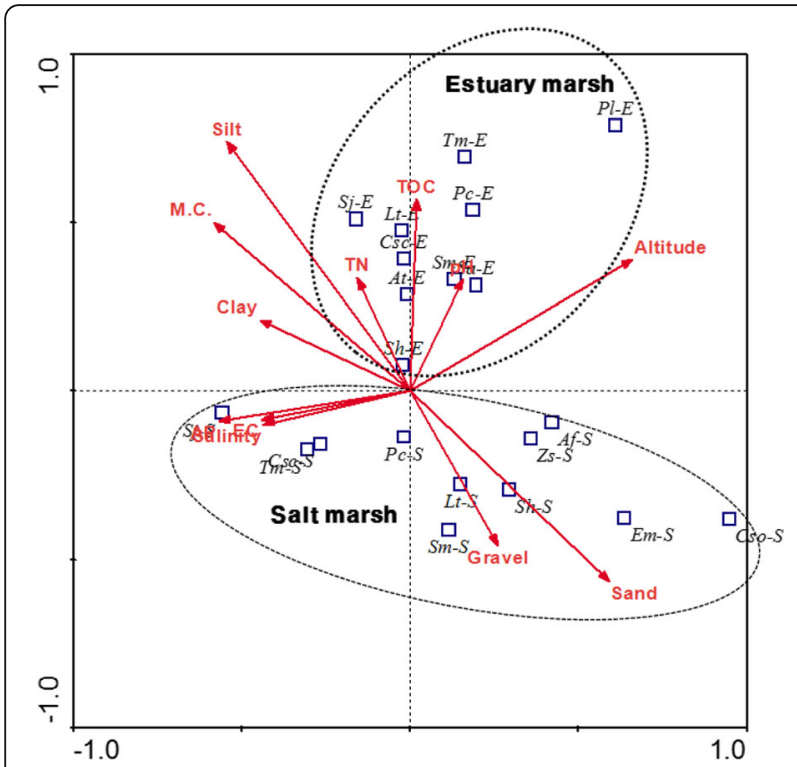

Fig. 6 Germination area of Suaeda japonica lined with tidal level in salt marsh atDonggeom (S2) in April of 2004

\section{Conclusions}

Halophyte distribution is affected by soil factors and outer physical influence such as wave and current. Because estuary marsh has a narrower altitude range but higher average altitude than salt marsh, halophyte distribution is less affected by outer physical influence. To induce growth or

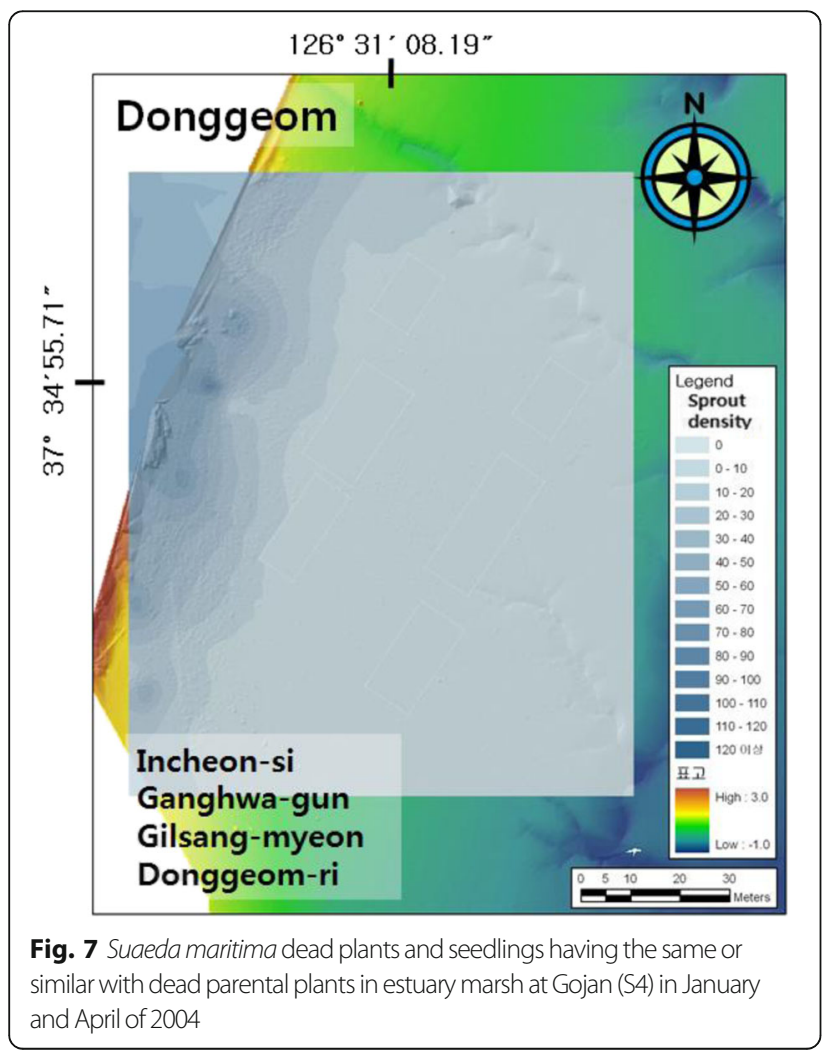

restore the halophyte considering the effect of seawater and sediment movement in salt marsh, a growth-inducing method that can decrease outer physical influence related to wave and current is needed. In estuary marsh, it is important to prevent seed loss caused by waves at area with high plant density.

\section{Methods}

\section{Study area and data collection}

Halophyte communities in salt marshes (coastal wetlands that are regularly flooded by tides) and estuary marshes (coastal wetlands where seawater meets freshwater) were sampled from Dongmak-ri in Gwanghwa-do (S1) to Hyeonhwa-ri in Muan-gun (S13) (Fig. 1 and Appendix 1). A total of 13 sites and 18 plots in the west coast of South Korea (total distance, $290 \mathrm{~km}$ ) were observed in this study. Coastal vegetation in these regions was monitored above 3 per community of each species. Except for S3 and S9, vegetation in all other sites were sampled from July 2004 to September 2014 and S3 from 2011 to 2012 and S9 in 2011. The relevé sampling method was performed using the phytosociological approach of Braun-Blanquet (1964). Dominance and sociability of all vascular plant species were included. The ecological gradient of plant communities was determined by the CCA ordination method.

By comparison of tidal elevation data in tidal station and altitude surveying data in intertidal zone, each altitude was determined in each community (from 2004 to 2014). To obtain topological conditions, Light Detection and Ranging Laser Radar (LiDAR) survey was conducted using Optech Ilris 36D. For leveling, MGL-3 DGPS was used.

Soil environment near roots was examined in five replicates at a depth of $15 \mathrm{~cm}$ (Fig. 3, Ihm and Lee 1998). Except for S4 and S9, soil in all other sites were sampled from July 2004 to September 2014, S4 from 2005 to 2009, and S9 in 2011. Air-dried samples were used for physico-chemical analysis. Moisture content (MC) was calculated as difference in weight between fresh soil and the same sample after oven-drying at $105{ }^{\circ} \mathrm{C}$. Total organic carbon (TOC) was determined by ashing the sample at $550{ }^{\circ} \mathrm{C}$ for $4 \mathrm{~h}$. Soil salinity, soil $\mathrm{pH}$, and electrical conductivity of soil:water (1:5) extract were evaluated using a salinity meter (YSI 63, USA). Soil available phosphorus (A-P) content was measured at a wavelength of $880 \mathrm{~nm}$ using a spectrophotometer (APHA 1989). Total nitrogen (T-N) was determined by the microKjeldahl method. Soil particle size was determined with a sieve according to the soil classification system (Ingram 1971; Folk 1954).

\section{Data analysis}

Distribution patterns of coastal plant communities were examined using the CCA method of Canoco program version 4.5 (ter Braak and Smilauer 2002). 


\section{Appendix Location of the study sites in the west coast of Korea}

Table $\mathbf{2}$ Location of the study sites in the west coast of Korea

\begin{tabular}{|c|c|c|c|c|}
\hline Site no & Name & Local name & Latitude & Longitude \\
\hline S1 & Dongmak & Dongmak-ri Hwado-myeon Ganghwa-gun Incheon-si & $37^{\circ} 35^{\prime} \mathrm{N}$ & $126^{\circ} 27^{\prime} \mathrm{E}$ \\
\hline S2 & Donggeom & Donggeom-ri Gilsang-myeon Ganghwa-gun Incheon-si & $37^{\circ} 34^{\prime} \mathrm{N}$ & $126^{\circ} 31^{\prime} \mathrm{E}$ \\
\hline S3 & Yeongjong & Yeongjong-do Jung-gu Incheon-si & $37^{\circ} 32^{\prime} \mathrm{N}$ & $126^{\circ} 33^{\prime} \mathrm{E}$ \\
\hline S4 & Gojan & Gojan-dong Namdong-gu Incheon-si & $37^{\circ} 23^{\prime} \mathrm{N}$ & $126^{\circ} 43^{\prime} \mathrm{E}$ \\
\hline S5 & Siwha & Dokji-ri Hwaseong-si Gyeonggi-do & $37^{\circ} 16^{\prime} \mathrm{N}$ & $126^{\circ} 40^{\prime} \mathrm{E}$ \\
\hline S6 & Daebudo & Daebu-dong Ansan-si Gyeonggi-do & $37^{\circ} 12^{\prime} \mathrm{N}$ & $126^{\circ} 36^{\prime} \mathrm{E}$ \\
\hline S7 & Jangdeok & Jangdeok-dong Hwaseong-si Gyeonggi-do & $37^{\circ} 08^{\prime} \mathrm{N}$ & $126^{\circ} 47^{\prime} \mathrm{E}$ \\
\hline S8 & Busu & Busu-ri Sinpyeong-myeon Chungcheongnam-do & $36^{\circ} 53^{\prime} \mathrm{N}$ & $126^{\circ} 49^{\prime} \mathrm{E}$ \\
\hline $\mathrm{S} 9(\mathrm{H} 1-\mathrm{H} 6)$ & Garolim & Garolim bay & $36^{\circ} 51^{\prime} \mathrm{N}$ & $126^{\circ} 20^{\prime} \mathrm{E}$ \\
\hline S10 & Jungseok & Jungseok-ri Hoehyeon-myeon Gunsan-si Jeollabuk-do & $35^{\circ} 54^{\prime} \mathrm{N}$ & $126^{\circ} 48^{\prime} \mathrm{E}$ \\
\hline S11 & Eunpa & Eunpa-ri Gwanghwal-myeon Gimje-si Jeollabuk-do & $35^{\circ} 48^{\prime} \mathrm{N}$ & $126^{\circ} 46^{\prime} \mathrm{E}$ \\
\hline $\mathrm{S} 12$ & Julpo & Julpo-ri Julpo-myeon Buan-gun Jeollabuk-do & $35^{\circ} 35^{\prime} \mathrm{N}$ & $126^{\circ} 38^{\prime} \mathrm{E}$ \\
\hline $\mathrm{S} 13$ & Hyeonhwa & Hyeonhwa-ri Hyeongyeong-myeon Muan-gun Jeollanam-do & $35^{\circ} 02^{\prime} \mathrm{N}$ & $126^{\circ} 25^{\prime} \mathrm{E}$ \\
\hline
\end{tabular}

\section{Acknowledgements}

This study was supported by a project (2014) of the technical development of conservational measures for marshy vegetation and endangered species in the wetland ecosystem funded by the Korea Environmental Industry and Technology Institute (KEITI). We thank Emeritus Professor Byung-Sun Ihm at Mokpo National University, South Korea, for his comments on the manuscript.

\section{Funding}

This research was funded with resources from Mokpo National University and KEITI.

\section{Availability of data and materials}

Please contact author for data requests.

\section{Authors' contributions}

The study was designed by JSL and SHL. SHL and JWK collected and analyzed. $\mathrm{SHL}$ has drafted the manuscript. All authors approved the final manuscript.

\section{Ethics approval and consent to participate}

Not applicable

\section{Consent for publication}

Not applicable

\section{Competing interests}

The authors declare that they have no competing interests.

\section{Publisher's Note}

Springer Nature remains neutral with regard to jurisdictional claims in published maps and institutional affiliations.

\section{Author details}

'Korea Environmental Technology Consulting Hotline, Ansan 15486, South Korea. ${ }^{2}$ Department of Biology, Kunsan National University, Gunsan 54150, South Korea. ${ }^{3}$ Department of Biological Science, Mokpo National University, Muan-gun 58554, South Korea.
Received: 10 July 2017 Accepted: 29 December 2017

Published online: 23 January 2018

\section{References}

Alexander, C. R., Nittrouer, C. A., Demaster, D. J., Park, Y. A., \& Park, S. C. (1991). Macrotidal mudflats of the southwestern Korean coast: a model for interpretation of intertidal deposits. J Sedim Petrol, 61, 805-824.

Alhdad, G. M., Zörb, C., Al-Azzawi, M. J., \& Flowers, T. J. (2015). Is the reduced growth of the halophyte Suaeda maritima under hypoxia due to toxicity of iron or manganese? Environmental and Experimental Botany, 116, 61-70.

APHA (1989). Standard Methods for the Examination of Water and Wastewater. APHA. Washington DC. pp. 1482.

Bird, E. C. F. (1984). Coasts: An introduction to coastal geomorphology (3rd ed.p. 372). Canberra: Australian Nationnal University Press.

Braun-Blanquet, J. (1964). Pflanzensoziologie. Grundzuge der Vegetationskude (p. 865). Wien, New York: Springer-Verlag.

Cahoon, D. R., Lynch, J. C., \& Knaus, R. M. (1996). Improved cryogenic coring device for sampling wetland soils. Journal of Sedimentary Research, 66, 1025-1027.

Cho, J.-S., Lee, J.-S., \& Kim, J.-W. (2017). Distribution of Phragmites australis communities with different habitat salinity. J Coastal Res, 33, 1210-1216.

Choi, J. Y. (1993). Seasonal variations of suspended matter in the Keum estuary and its adjacent coastal area. J Oceanol Soc Korea, 28, 272-280.

Chung, G. S., \& Park, Y. A. (1978). Sedimentological properties of the recent intertidal flat environment, southern Namyang bay, west coast of Korea. Ocean Sci J, 13, 9-18.

Costa, C. S. B., Marangoni, J. C., \& Azevedo, A. M. G. (2003). Plant zonation in irregularly flooded salt marshes: relative importance of stress tolerance and biological interactions. Journal of Ecology, 91, 951-965.

Dalling, J. W., Swaine, M. D., \& Garwood, N. C. (1998). Dipersal patterns and seed bank dynamic of pioneer trees in moist tropical forest. Ecology, 79, 564-578.

Davidson-Amott, R. G. D., van Proosdij, D., Ollerhead, J., \& Schostavk, L. (2002). Hydrodynamics and sedimentation in salt marshes: examples from a macrotidal marsh, Bay of Fundy. Geomorphology, 48, 209-231.

Folk, R. L., \& Ward, W. C. (1954). Brazos river bar: a study in the significance of grain size parameters. J Sedim Petrol, 1954(27), 3-26.

Glenn, E. P., Nagler, P. L., Brusca, R. C., \& Hinojosa-Huerta, O. (2006). Coastal wetlands of the northern Gulf of California: inventory and conservation status. Aquati Conserv, 16, 5-28.

Gul, B., Ansan, R., Flowers, T. J., \& Khan, M. A. (2013). Germination strategies of halophyte seeds under salinity. Environmental and Experimental Botany, 92, 4-18. 
Harper, J. L. (1977). Population biology of plants. London: Academic Press. Hong, JS (2000) Biodiversity of macrofauna on macrotidal flats, Inchon, Korea. Program and Proceedings of International Symposium. The Korea Society of Phycology, Seoul. p. 45-58.

Hubbel, S. P. (1980). Seed production and the coexistance of tree species in tropical forests. Oikos, 35, 214-229.

Ihm, B. S., \& Lee, J. S. (1998). Soil factors affecting the plant communities of wetland on southwestern coast of Korea. Korean J Ecol, 21, 321-328.

Ihm, B.-S., Lee, J.S., Kim, J.-W., \& Kim, J.-H. (2006). Effect of soil factors on vegetation values of salt marsh plant communities. J Ecol Field Biol, 29, 361-364.

Ihm, B.-S., Lee, J.-S., Kim, J.-W., \& Kim, J.-H. (2007). Coastal plant and soil relationships in the southwestern coast of South Korea. J Plant Biol, 50, 331-335.

Ingram, R. L. (1971). Sieve analysis. In R. E. Carver (Ed.), Procedures in sedimentary petrology (pp. 49-67). New York: Willey-Inter Science.

Ivajnsic, D., Sajna, N., \& Kaligaric, M. (2016). Primary succession on re-created coastal wetland leads to successful restoration of coastal halophyte vegetation. Landscape Urban Plan, 150, 79-86.

Kim, C. H., Cho, D. S., Lee, K. B., \& Choi, S. Y. (2006). Population formation strategies of halophytes in Mankyeong River Estuary. Korean J Environ Ecol, 20(3), 299-310.

Kim, S. Y., Jung, K. K., Kim, B. M., Lee, Y. G., Choi, Y. S., \& Kim, S. (2008). Geochemical characteristics in the costal wetland and intertidal zone of Suncheon Bay. Journal of Wetlands Research, 10, 81-96.

Kirwan, M. L., \& Guntenspergen, G. R. (2012). Feedbacks between inundation, root production, and shoot growth in a rapidly submerging brackish marsh. Journal of Ecology, 100, 764-770.

Konisky, R. A., Burdick, D. M., Dionne, M., \& Neckles, H. A. (2006). A regional assessment of salt marsh restoration and monitoring in the Gulf of Maine. Restoration Ecology, 14, 516-525.

Korea Environment Institute (2006). Study on the effective mitigation measures of coastal erosion due to coastal developments. Korea Environment Institute. Sejong. pp. 630.

Lee, D. G., \& Yoon, S. Y. (1999). A study on the economic evaluation of conservation value of coast wetland - a case study of Kang-Hwa island. The Industrial Science Researches, 7, 141-154.

Lee, J.-S., Ihm, B.-S., Cho, D. S., Son, D.-Y., \& Kim, J.-W. (2007). Soil particle sizes and plant communities on coastal dunes. J Plant Biol, 50, 475-479.

Lee, J. S., Ihm, B. S., Myeong, H. H., Park, J. W., \& Kim, H. S. (2009). Soil environment analysis and habitat of halophyte for restoration in the salt marshes of southern and western coasts of Korea. Korean J Plant Res, 22(1), 102-110.

Lee, J. S., Kim, J.-W., Lee, S. H., Myeong, H.-H., Lee, J.-Y., \& Cho, J. S. (2016). Zonation and soil factors of salt marsh halophyte communities. J Ecol Env, $40(1), 1-4$.

Lee SH (2011). Distribution of halophyte communities along altitudinal gradient and the growth induction of the vegetation in salt marshes. Ph.D. Thesis, Mokpo National University, Mokpo.

Lee, S. H., Lee, J. S., Ihm, B. S., \& Chae, J. H. (2014a). Halophytes biological introduction using small fences and water channels at the estuary marsh of Gojan. Journal of Korean Environmental Dredging Society, 4(1), 12-20.

Lee, Y.-K., Park, W., Choi, J.-K., Ryu, J.-H., \& Won, J.-S. (2014b). Halophyte die-off in response to anthropogenic impacts on tidal flats. Estuar Coast Shelf S, $151,347-354$

Liu, S. W., Zhao, C., Zhang, Y., Hu, Z., Wang, C., Zong, Y., Zhang, L., \& Zou, J. (2015). Annual net greenhouse gas balance in a halophyte (Helianthus tuberosus) bioenergy cropping system under various soil practices in Southeast China. GCB Bioenergy, 7, 690-703.

Maeng, J. H., Cho, K. W., Kim, H. S., Park, H. N., Hong, J. S., Yoo, J. W., \& Lee, C. G. (2007). Improving environmental assessment in tidal flat reclamation (p. 154). Sejong: Korea Environment Institute.

Min, B. M. (2000). Distribution of Acer palmatum seedlings under the crown of the maternal tree. J Plant Biol, 43, 33-40.

Min, B. M. (2005). Seed distribution and burial properties of Suaeda japonica in tidal-flat. Korean Journal of Ecology, 28(3), 141-147.

Nyman, J. A., Walters, R. J., DeLaune, R. D., \& Patrick Jr., W. H. (2006). Marsh vertical accretion via vegetative growth. Estuar Coast Shelf S, 69, 370-380.

Oh, J. K., \& Bang, K. Y. (2003). Sedimentologic linkage of depositional environments of Han River and Kyunggi Bay, Korea. Ocean Sci J, 8(3), 225-236.

Okubo, A., \& Levin, S. A. (1989). A theoretical framework for data analysis of wind dispersal of seeds and pollen. Ecology, 70, 329-338.
Park, E. J. (2000). The spatial characteristics of vertical accretion rate in a coastal wetland -in case of Sunchon bay estuarine marsh, south coast of Korea. Journal of the Korean Association of Regional Geographers, 6(3), 153-168.

Park, M. J. (2008). Tidal characteristics change in the Asan Bay due to the Hwaong (Namyang Bay) Tidal Barrier. Ocean Sci J, 13(4), 320-324.

Park, T. Y. (1999). A study on the management planning for the conservation and environmentally friendly use of Korean coastal wetlands. Journal of the Korea Society of Environmental Restoration Technology, 2(3), 64-73.

Rogel, J. Á., Ariza, F. A., \& Silla, R. O. (2000). Soil salinity and moisture gradients and plant zonation in Mediterranean salt marshes of southeast Spain. Wetlands, 20, 357-372

Sin, M. H., \& Kim, C. H. (2010). Traits of control by sluice gates and halophyte community formation in Saemangeum. Korean J Environ Ecol, 24(2), 186-193.

Ter Braak, CJF, \& Smilauer, P (2002). CANOCO reference manual and CanoDraw for Windows user's guide: software for canonical community ordination (version 4.5). Microcomputer power, Itaca, NY, USA. http://www.canoco5.com.

Viles, H., \& Spencer, T. (1995). Coastal problems: Geomophology, ecology and society at the coast (p. 352). London: Edeward Arnold.

Wells, J. T., Adams, Y. A., \& Frankenberg, E. W. (1990). Morphology, sedimentology and tidal channel processes on a high-tide-rage mudflat, west coast of South Korea. Marine Geology, 95, 111-130.

Willson, M. F. (1992). Dispersal mode, seed shadows and colonization patterns. Vegetatio, 107(108), 261-280.

Xie, T, Cui, B, Bai, J, Li, S, \& Zhang, S (2017) Rethinking the role of edaphic condition in halophyte vegetation degradation on salt marshes due to coastal defense structure. Physics and Chemistry of the Earth. doi:https://doi.org/10.1016/j.pce.2016.12.001.

Yokoishi, T., \& Tanimoto, S. J. (1994). Seed germination of the halophyte Suaeda japonica under salt stress. Plant Res, 107, 385-388.

\section{Submit your next manuscript to BioMed Central and we will help you at every step:}

- We accept pre-submission inquiries

- Our selector tool helps you to find the most relevant journal

- We provide round the clock customer support

- Convenient online submission

- Thorough peer review

- Inclusion in PubMed and all major indexing services

- Maximum visibility for your research

Submit your manuscript at www.biomedcentral.com/submit 